\title{
亞炭乾溜に關する座談會
}

日時昭和 23 年 11 月 23 日

場所燃料會 館 講 堂

出席者 (敬棦略)

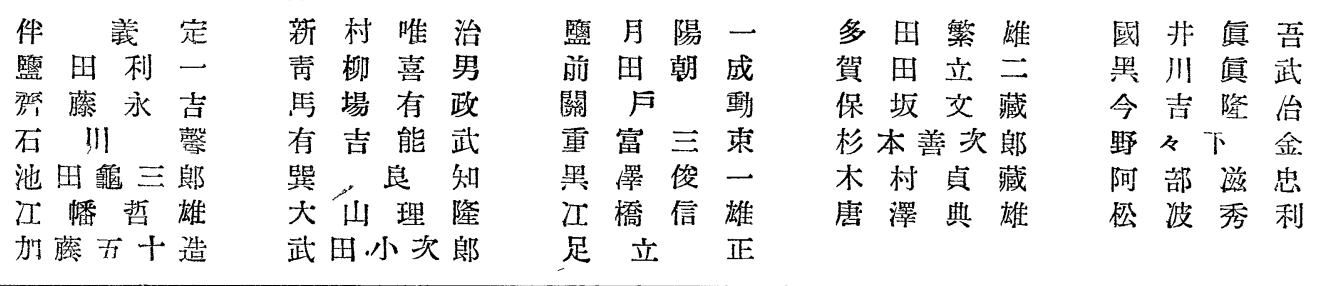

“件氏 只今より亞炭䓽溜に關する座談會を開催した いと存します。御败しい所竞多數の方々か御出席下さ いまして有難らこざいます，つきましては會の進行上 座長として賀田さんを御願い致したいと思いすすか皆 樣の御賛同を打願い致します。

賀田氏 御指命によりまして私か座長をつとめさせ て戴きすす。時間か少い關係上時間を有效に使い，こ の會には實際に事業を經營して居られる方々か多數集 つて居られるのてありますから, 亞炭乾溜に就ての有 效な結論とむては行かなくとも，その方針を示したい と思いすす。

最近亞炭業界は不振てあります。このま〉ては前途 に行詰りを生する恐れかあります。これを何とか打開 して行く弯にも今後此の亞炭の加工による品位の向上 といら事を考之てみなくてはなりません。之か我々亞 炭閣係の者に課せられた使命てあり，叉之により初め て亞炭業界を振興させ得ると思らのてあります。

現在日本都市に於ける燃料の需要は木炭にして 40 數俵, 切りつめてる30 數俵を必要とするのか, 供給 量は僅か 16〜7 俵に過きす,一この不足量を亞炭に俟つ と云う現狀でりなから，又佢炭界ては之を家庭燃娬

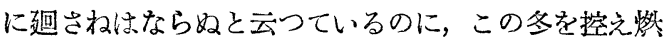
料の需要の盛な時に此の處亞炭，亞炭コークス及コ一 ライト等の需要は極めて少い,このわけは何てしよう か。この理卅は明かてあります。郎ち品質か惡い，價 格か高い等謜因て，例宎は有效熱量上り計算致しま

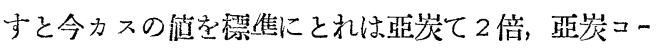
クスてはれ當り 1 萬〜12 萬圓となり 3 倍となつて居 ります。結局品質の艮い物加出來なけれは賣れない, 買手かないと云らことになりすす。今後家庭燃料の補
充としては 20〜30萬 $\mathrm{t}$ の亞炭コータスを製造しなけ れはならないか，午の品質，價格の兩面に於て改善す へき餘地か多々あると思らのてあります。此の座談會 に於きむしては價格の敤るさりなから，品質の改良に ついて，このことのみてはありませんか，討䜗を進め て行きたいと思います。進行の順序としまして第 1 に 乾溜加工用原料として如何に良質のものを得るか，第 2 に乾溜裝置，操作は如何にすれはよいか，第 3 に亞 炭コークス，其他裂品及副座物の處理は如何樣にすれ はよいか，と云うことて話を進めて行きたいと思いま 寸。

先つ炭亞の取引てありますか亞炭は今もつて容量 $\mathrm{t}$ て取引をされて居ります。重量 $\mathrm{t}$ か良いか容量 $\mathrm{t}$ かよ いかは以前より問題とされている所てありますか，亞 炭は大體常枯て取引をすれは水分は山て定つている 筈でから買入れたものはとれ位になるか決つて來ま す。此坫から云えは重量 $\mathrm{t}$ の方か良く容量て行万のは 矛盾かあるのてはないてしょうか。しかし山元て常枯 てなく掘出したはかりの水咑のま入报らことか多々あ り茲に問題が㔚こります。叉品質改良の手段として手 選，水洗等の方法も岁りますか又これ問題てあると 思いなす。

加工亞炭は家庭燃料不足を禣万孚にも 今後年 20〜 30 萬 $\mathrm{t}$ の生產を要求されて居りますか, 都市の家庭 燃料を背負つて立つからには, 原料亞炭として灰分 20\%， ニークスとして 30\% まての品質の物を製造し なくては䭾目でろろと思いむす。此等の種々の問題 につきましてこれから忌憚のない御意見を御願い致し むす。

伴氏 日本の亞炭て灰分による品位別の生產量はと 
らなつて居るてしよらか。

監月氏 只今此處に數字は持つて居りませんのては つきりしたことは申せまんか，炭質別て異つて居りま 特，特 1 と特 2 か灰分 $20 \%$ ，一番多いのか 1 級て 灰分 22〜23\% のbのて, 之を调查對象の 650 坑につ き生産量の 240 萬 $\mathrm{t}$ て割合を出してみますと， 1 級 以上が牛はを占めて $100 \mathrm{t}$ 萬以上てあります。

賀田氏 30 萬 $\mathrm{t}$ の亞炭ゴークスては原料亞炭乃 100 萬 $\mathrm{t}$ 必要てすね。20\% の灰分は無理て 25\% 位迄 と云うことになりますか。

その品位に關聯してですか，試料探取，分析は公團 てやつて居りますか，公團の分析數值か平均試料に基 いているか，何處まて信用てきるか，つまり公團の分 析の權威と云らことになりますか之は如何てしょう。

臨会氏 大體はいいのてはないかと思つて居りま 寸。

關戸氏 試料の問題てすが公團の分析ては櫭して本 均試科となつて居りますが，正直に云つて或程度疑閣 のある蛅も無いことはないと思いすす。

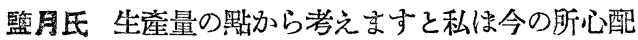
はないと思つて居ります。*

賀田氏 そらしますと乾燥烒料て灰分 $25 \%$ のるの か100萬 $\mathrm{t}$ は大手か可能と認められると思います。 佾当ら一つの問題として各々の炭坑て自分の所の品位 を向上させると云らことは出來ないものかと思らのて すか，現在㫮樣かやつて居られる方法の內て，今少し 灰分を少くする方泆はないてしよらか。ボタを取ると か，陝衣を拔くとかの方法はありませんか。或岸坑て 䖦る炭にンャローをかけて表面に附いているホタを 除去し，年れを選別すると方泆を取つて居るとうてす か，其以外に方法はありませんか。

保坂氏 私は以前東北て 7 年はかり亚炭に關係致し て居りまして，其の間の事情を申しますれは，當時は 1 貫 1 錢〜2 錢, tて 4 圓加 5 圓位のものてあり, " それてる品質の踔から需要かなく加工亞炭の方に氣運 か闹いた樣てすか，昭和 15 年頃より石炭の需要か增 し統制か始り，それにつれて禣助然料てある亞炭力注 交をらけ需要加急激に墰之，折角向いた気運马立消之 となり業者は乾溜等せす專ら亞炭の價格を吊上けるこ との反に腐心すそ樣になつたと云つてる過言てはあり ません。その妝態か現在迄續いているのてこれては加 エ々業か成立つわけはありません。再び頭を下けて買 つて望5時代にならなけれは仲々乾留は行われないて しよ5。しかし私は之から市場出す严炭の品位は水 分 $30 \%$ 以下，灰分は賀田さんの云われた樣に $25 \%$
以下て，而る價格はもつと低くならなくてはいけない と思います。之等の事から亞炭は加工しなけれは市場 性かない，加工してこそ亞炭は生きて行けるのたと云 らことを强調し，このま〉ては亞炭は衰しすると云う ことを云いたい。業者の方々もよく現在の狀態を見 て，最早以前の樣な量をのみ多く生爰すれはよいとの 考えを是正して生亞炭の價值の低いことを再認識しな け扎はならないと思います。

又價格の䗉についても今迄㤝生產者向てあつて加工 業者の事は一向に考慮されていなかつた，又容量 $\mathrm{t} の$ 問題孔 $40 \mathrm{ft}^{3}$ を $1 \mathrm{t}$ としているが，之は石炭のこと て亞炭には不適なるのてはなかららか，杂れから分析 試料について子生産者は試料として特に良質の者を邆 る倾向かあります，この梂な博覽會へ出す栐な訊料て 分析してそれてその結果から炭種に 1 級 2 級と等級を 附寸樣な爿態てす。實際掘つた時は水分か $50 \%$ 以上 るあるのに其椂な結果の出ている所は見當らない。熱 量は特に特別の試料て分析をされているし灰分它相當 の峳動かある事等不合理な蛅力多い，關係方面に招か れても今後此等の事を充分調查され改害していかなく。 てはいけないと存します。又良質炭年產 100 萬 $\mathrm{t} の$ 問題はこれからの亞炭は加工しなくてはやつて行けな い位てあるのて量的には心配いらぬと思いすす。

咀四氏 ともかく加工には原料の良い物か入手出來 る事か必要てす。又只今の容量制, 重量制の問題につ いては容量央量共に建値そなる楾にすへきて，私は各 炭抗每に其炭種の常枯㓠態を嚴密に䛸查し各山につき 格付をし別個に容量 $\mathrm{t}$ を決定すれは問題ないと思いま す。加工業者の方は其使用原料炭の中少くと必斗分以 上は自分の意志て動き，山行つて自分の要求に合万 樣にするのか望しいと思います。この核てなくては經 管影困難と思います。

保坂氏 先程特話した東北の亞炭坑ては昭和 12 年 頃より實驗的に選炭をし，大塊は手選，中小堍粉は 機㭜選を行いむしたか，成綪もかなり良好て現在直ち に開始するには種々困䧼力件らてしよらか，やつて出

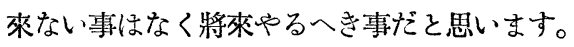

賀田氏 燃研に於きまして亞炭の選炭の實驗を行い ましたか，之も相當良好な結果を得，牲炭の不可能て ないことか䗳明されました。現在ては出來ませぬか今 後の選炭の行き方として個人て先炭機を持つ事は難し い故，地方別にフロノクを作り大規模の選炭工場を設 置して共同て選炭をしたら如何てしょうか。そして良 質物は潠炭し，選炭の困蜼な炭はすく燃やすなりすれ はよいと思います。この㧼にして良質炭のみを加エし 
灰分の多い物等は家庭用に迴したり致しすす。之も直 ちに實行に移すと云うわけにはいかないか，將來の問 題として必すやる必要かあります。

以上て原料炭關係は絡りと致しをして次に乾溜に關 する事項に移りたいと思いすす。現在亞炭乾溜の最大 の㟪題は良質のるのを多量に而它安價に供給すること てありまして，乾溜に際してカス，タールを取ること るけが，現在では良品質の亞炭コークスを得ること か㵊大目的てある故之等は戬牲とし，このため私の考

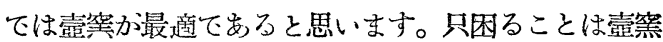
の現狀ては止むを得ないこ兵と虻思いますか，粉に灰 が多いことて，平圴して粉は塊より約 10\% 灰分か多

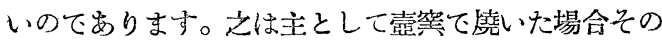
コークスが部堯け灰化してやせてそれか粉化し易い ためと思われをす。前の括ては严炭の場合壹燒爐で 處理した際原料炭の 12 13\% 力燃燒して熱源となる 樣な乱話たつたか，私は石炭の場合て 2 割內外亞炭の 場合亞炭は水分か多いから他の加熱用熱源のない場合 は原料の 3 割は燃之灰化していると思います。郎ち 3 割相當の灰か墂加していることになります。これを熱 量て考之ると爐內て熱量の 6 割內外を水蒸氛に喰わ れ、コークスは2亚，殘りがガス其他に消費された事 になります。丑今日の姡ては 4〜5 割のコークスが

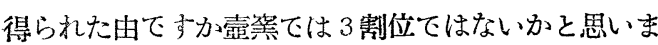
す。一般にコークスの得量はかりを云われる傾向か蜜 りますか，灰の堛す事も云つて頂きたいと思います。 以上の礵上り考兄ますと乾溜装置にはるつと費用をか け挸模を大きくして完備したものを製作した方かよい そ考元られます。ともかく生成コークスの犋を向上し 且經齋的な裝置を考㝋てみなけれはならないのですか ら，此點に就きむして皆樣の御意見を伺いたいと存じ ます。

ル、キ式ては加熟用燃料と上て生成する亞炭カ スの みては不足し，2/3 程は他の燃料を必要とします。こ れは亞炭ては乾溜力スの生成量は石炭の低溫乾溜の場

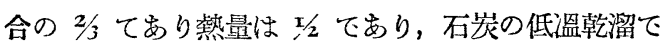
はガスか所要熱量を充すに一杯てある故でります。

盛田氏 乾溜爐としましては純內熱儿、キ式てあり ますと建設費る高くなり，內熱式の生空氣を吹込む方 法ですと建設費は安いか灰分を增しコレクスの品位を 害すると云り缺點か女り，この中間をとり先程申上げ ました方法を探り吹达熱氮中に空氣を混入する方法 でこれに依れは成品の質淩大體均一となり灰分の混 入は殆となく運轉終了の際少量㐫と云つた程度てあ ります。
賀田氏 お話しの空氣は爐の中て亞炭を燃燒させる 譯でから，亞炭自體か燃えそれか洃となつて殘るで しょ5。直接ガスと空氣とを一諸に吹込みますと燃燒 溫度は $600^{\circ} \mathrm{C}$ 內外になるか 亞炭の 着火溫度は $400^{\circ}$ 近邊てありむすから過剩空氣の吹込により局部的に吹 込の坫たけか燃えコークスの溲せの方か助長されるの ではありませんか。これには出來るたけ乾燥した原料 を使らことも大切たと思います。叉ガス又は蒸氮て稀

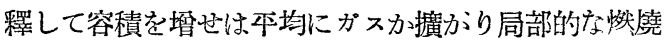
は防止し得ると思いすす。

監田氏・しかし吹込久の方法を考慮しこの惡影響を 少くし得る事る出來ると思います。郎ち賀田さんの言 われた通り吹达っスを他のものて稀䆁するとか，廣い 面積に分散させて吹达むとか云つた方法てす。又燃燒 爐の下に水槽を設け蒸㲵を發生させて之れて稀䆁する とか叉周圍より渦叁き爿に吹达む方法を考えて屈りま す。

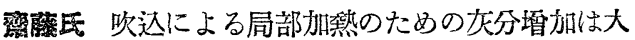
した事はないと考之られます。慍度か昇れは灰分か唔 加致しますか，壶㝘てすと一般に 500〜 550 ${ }^{\circ} \mathrm{C}$ 上に はならす唯下部から生空氣か入りますと 7 800 $に$ もなります。ですから壹燒熆に依れは灰分か多いる云 われるか操作を上手にすれは 12〜3\% の燃料て濟み外 熱式に比較してあまり抙色ないと思います。

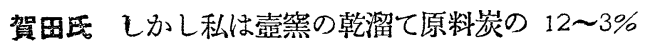
の燃然て乾溜し得ると云らことに對しては疑間を持つ て居りまして，計算致しましても熱量か不足している と思います，もつと多く燃えているのてはありません か。

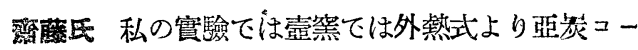
クスの得率か 12〜3\% 少いのでそれたけか燃料として 消耗されたと見ました。壸案は非常に効率かよいのて 燃料は少くてすむりのと思われます。壸燒を致しむす そ灰にならぬ內に消火し通風の工合さえ充分注意すれ は灰化は少く，灰のついたコークスは出來ますが灰の 量と云つては少いるのてす。

賀田氏 亞炭の場合は全體に瘦せている場合は見掛 けは餘り變化かなくても灰化か進んていて，局部的に 蜘えてる場合には灰か洺い、漾に思い易い，そこに誤解 があるのてはありませんか。とにかく乾溜にはある絕 對量か如何にしても必要てあつて，之は能の倉の例て すがリラム鑵を利用して乾溜爐を作り橫に孔を開け初 めは外熱式，後ては生成カスを利用して空氣と共に內 熱式に燃燒する樣にしたるのて，此式によつてる私は とらして子乾溜には原料の 3 割は必要たと思いまし 
歫。

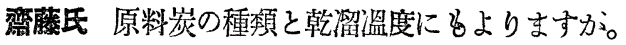

保坂氏 熱量力乾燥にはとれ程必要吕，乾溜に如何 程必要加䃑究されていないのてすか，完全に乾燥し て居れは乾溜の熹量は少くて濟むと思万のてすか。

賀田氏 燃料研究所てしむした結果はありますが大 體石炭の場合は 2 割，亞炭は水分の關係て 3 割程度は 必要とする樣です。又炭翼によりまして異るのて一概 には云之ませんか，一般加工用原料亞炭は本均 $20 \%$ 程度の水分を含むのて御說の通りには行かぬを思いま す。

羉川互 亞炭の場合は石炭の場合の 2 割と云5のと は大分事清か異なるのてはありませんか。石炭の場合 は揮發分が相當濃いのに比へ亞炭ては發生した揮發分 か丁度燃燒に適當した位に稀く比較的有效に揮發分か 使われて居り，乾溜か行われ小は卧炭かすく溜せるの てはないのではりませんか。でありすすから必要熱 量はそら簡單には計算出來ないのてはありすせんか。

賀田氏 しかし乾溜亞炭の品位を2まず粉の部分 に特灰分加多く之は先程中しまし核に乾溜による

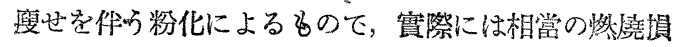
失か涉ると云引登據たと思います。

保坂私の考光ては外熱式と異なり七等ては消火 するのにホタや灰分の多い物をかけるのて其か枌に灰 か多いと云われる原因となづているのてはありません か。

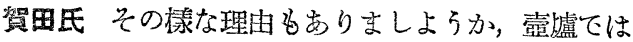
3〜4 割の粉加出來, やはり初めからの亞炭の乾溜に 上る粉化の倾向か原因たろらと思いすす。

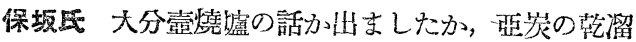

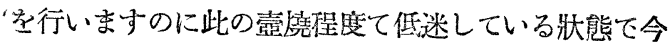
度制定された家庭用の規格に合格するコークスか出來 るてしようか。

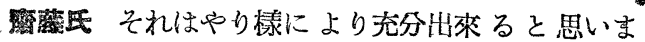
す。先程より粉分か塊上り灰分か多いと云う特話かあ りましたか，私の實驗ては塊に比へて僅か 6〜7\% 多 い程度てした。 。

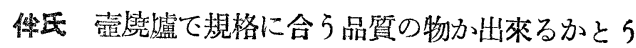
かと云万疑間に對しまして私は次の如く考えて居りま す。郎ち勿諭䙺模の大きい優秀な乾溜虎索作る事は申 分ないことてすか，今日の亞炭の事業の程度からみま

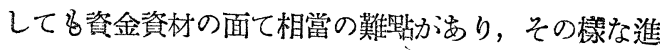
步的な方面はかりを見て居れなせ奴と申しましてる 盇燒盧は必すしも規格に合格するものはかり出來るも

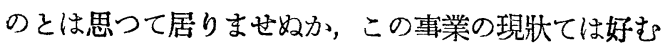

と好さざるとにか〉わらす，この壹燒爐程度の物より 始め逐次改善し一步つ〉前進し將來は理想的なるのに 迄扎進めて行くへきと思つて居ります。此の意味て 當座は壹燒の砄究をするのb充分意義のあることでは ないかと考えて居ります。

賀田 今後は會長の云われる樣に壹羣を改善し優 れた装置を設ける樣にしていかなくてはなりません か，現在の辜燒の方法て灰分の少いるのを出す方法は 岁りをせんか。コークスの品質を重く考之れは現在の 盇空をもつと改良せねはなりません。，

体瓦 その通りて現在のまってはいいとは思いませ ん。しかし壹烓たからと云つて灰分か多いと云らのは 當つて居りません。一般に壹燒をしている所は小規模 な企業て乾溜接術力拙乓てあるのでるるめと思いま す。

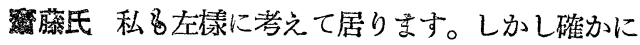

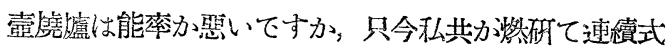

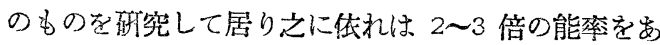
け好結果を得られるのてはないかと思つて居りをす。 要は壸燒式ても丁窑に操作学行えはよいと思います。

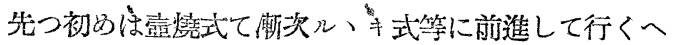
きと考之て居ります。

保氏 例か可笑しいか子分りませんかホイラーの焚 燒の場合かそらてありまして，近頃新式のストーカー か普及して好成績を上げている㧼です，未た手焚き の所句相當にめり夫々其特徽を發揮して居り，スト一 カー必すしも理想的な結果を與えて居らす，手焚きも 熟練さえすれは敢て機械焚きに劣ら始果を與えま す。亞炭の乾溜の場合も此と同栐てありをして，唯其 手焚きか下手てありては困るのてありまして此の意味 よりしまして壸然の操作の點に心して行ろ必要かあろ らと考㝋ます。

保碾氏 先日テパートて賣られて居りました亞炭コ

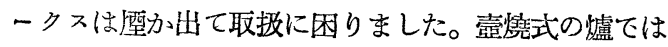
このいふらないコークスを作るのは困難てはないかと 思いすすか。

賀田氏 壹埃盧のものたからいふるとは云えないと 思いすす。壸弿は種々あるのて一例を以て全てを推定 するわけにはいきません。その技術を向上させて行け は品質は進むるのと思います。壹熱盧を操う熟練次第 て或程度品質はカハー出來るではないでしょ5か。

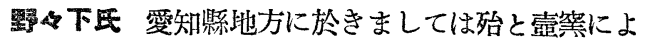
り處理して居りますか，步留りは多少落ちる樣てすか

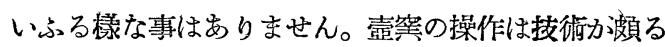
、關係するのてありまして，一般に未熟の工員かやつて 
居ります故製品にむらか多く今後は熟練次第て品質む 向上すること〉思います。

翼氏 $\mathrm{t}$ 當りの製帝原價は爐式によつて何れ位異り ますか。

賀田氏 外熱式たととらして子燃料費か多くか〉る 栐ですね。少い肯のて原料の牛分位ですね。

前田氏 先程の話に出ましたか䆠燒盧の灰の問題て ありますか，之は原料炭から來る原因か主てありまし て選炭しないるのを使用した際か灰か一番多く, 賀田 さんの言われる如く燃堯による灰化のめたと云了理由

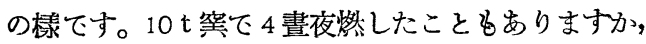
技䘗熟練者か居らす製造工程にむらかあれは灰も多く なる原因となり，之は大體 1 畫夜位て止めた方かよい てしょら。

又製品のむら，いふり，灰分の多いことは人的の問

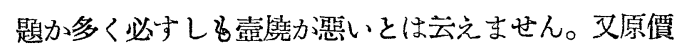
としまして嚧の種類により 3,000～6,000 圓になりま 导。

多田氏 私共の所ては探掘したものは水分約 $50 \%$ ， 灰分 5\%て，之を水分 20\% として木質部灰分 $8 \%$ ， 炭質部来均 10\% のものを使用しており，建設費は勿 論容量により異りますか壹空月 $300 \mathrm{t}$ 程度のるのて 10 萬圓て, 之か外熱式たと 2 300 萬圓はかかるてし よう。私共の方ては外熱式を探用致して居りますか之 は昔の施設を利用しそれを改造しているのてあつて, 新えに建設するのは仲々困難てしょう。

一般に薪規に開始するには外熱式ては幾度も試驗を してみなくては危險てありますか，外熱式てあります と他と比較にならぬ程の良質の製品か得られます。

國并氏 コストの問題てありますか石炭の場合はそ の價格は現在赤字てあり相當な無理かあります。其上 設備は昔の物を使つて居り等す。亞炭の場合は新しく 設備を作つたりする關係もあり, 今の石炭の價格と比 較するのは無理たと思います。

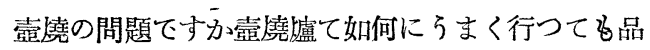
位は或程度制約されます。今後は壹燒は壶琵てやり, 機械は機㭜てやると云つた榬に各々勝手に研究するよ りも多くない國の費用てはありましょうか，徹底的に 大大現模に研究して改良して行けはいいのてはないてし よう力。

賀田氏 亞炭の內熱式乾溜としては結局ル、キの原 理を應用した途に進むへきたと思いますか，ル、キて は出たガスて乾燥乾溜をするのてすか亞炭のガスては 熱量加不足すると思います。此等の磍字會社自身の

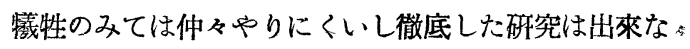

いと思います。

鹽月氏 實際の問題と致しまして预算の關保上思 5 樣には仲々出來ません。今後相當むをむつた豫算を使 つて鿬究をし，亞炭の乾溜により優秀なコークスを多 量供給することは他の電力, 石炭等の問題に比し效果 は遥かに大てあります。この柡な機會を利用し此の問 題を與論として政府, 國會へる進言して亞炭業振興に 努力して行きたいと願つて居ります。

國并氏 少々の事てはこの問題は仲々解決出來ませ． ん。穖楎として安本に一つの廳位を作つてやる位の意 氮达か欲しい。未た破究の餘地は充分にあるのてすか ら例えはル、キか良いと云えは國か之を買つて試驗を する位になれは良いと思います。

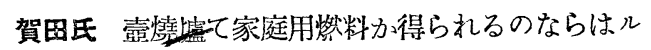
、キ等は問题にならないと思いますか。

國井氏几、キを用いる事はカスの不足の啙てます いと云われましたか，炭種の選定其他を考えれは良い 結果を得られると信じて居りますか。

賀田氏 いや其の樣な意味て申したのてはありませ ん。原理は結溸てすか，吹込がスを何とか質的によく したい，熱源として石炭の場合の 3 分の 1 程度しかな いのてすから。郎ち 3 分の 2 は不足しますから。

國井氏 發生カスの不足のことは炭種により乾溜方 法により變化します。石炭の場合は低溫乾溜にはなる へく溫度を低くし丁度っスか一杯になる樣にして居り ますか，亞炭の場合はるつと盗度を上げれは發生カス の熱量子上昇し旦量子多くなるのてはありませんか。

多田氏 發生カスの量と熱量について私の實驗の 結果を申上けますと，量は 130〜160 $\mathrm{m}^{3}$ 位，熱量は 3,000 4 000 Cal となります。之を完全に加熱用に使 用すれは少々不足する程度てあります。計算を致しま

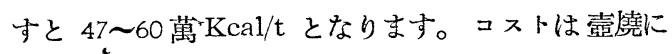
比して之倍かるると云う話てしたかタール等の副產物 の佨收を考光れはコストはそ万高くはないと思いま 与。

重富氏 建設費維持費から考えて壹燒と機践化した ときのコストの至は如何てすか。

前田氏 月 $500 \sim 600 \mathrm{t}$ 程度の爐を使つてみすすと， 外熱式は當然コスト高となりますか, 今後次事用亞炭

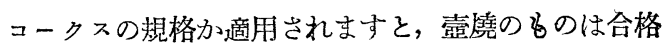
品は 2〜3 割, 穖㭜化したものは 6〜7 割は合格する 等の點より考之何れかよいか制らなくなりすす。

賀田氏 操作法の不備火より汾化することか多く, 塊 と汾とは格段の價格の差かありますから例えば粉は約 3,000 圓塊たと 6〜7,000 圓となる堎て，塊を多、出 
す棱にしなくてはならす，此嘲より考えて外熱式は相 當な利點があるてしよう。

体氏 現在乾溜は山元て行われて居りますか，製品 は粉は使用上困難を感じ，又製品の運搬中に粉化寸る と云らことも考えなくてはなりません。山元て塊は 80\% と云つていてる需要者の手に痩る時は其のデー ターと異つた結果か出ることになります。將來はと 5 しにも亞炭の加工は消費地に近い所てすへきたと思い ます。

監月氏 これには經䜞的な閏題かついて來るてしよ 弓。

俣站氏 亞炭の乾溜に先立つて穊別乃問題になると 思いますかとの程度に抢やりになつてみえますか。

國井氏 粒度に特に差か著しくなけれはその嫿用い て居りますか，尤子粉の細いるのかありますと㠠内の 抵抗か問題となつて來ます。

賀田氏 乾溜榬置を永く使用して居ますと出る酸て 裝置か腐蝕されませんか。例えはター几除去，冷却の 裝置等か。

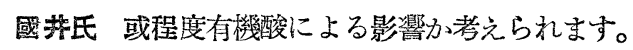
試驗をして居りますか，タールか绲して居りますをす つと腐蝕力少い㧼てす。理由は分りませんか醋酸等か まつてもクレッールかあれは腐蝕は少い裉てさ。

賀田氏 大分時間も經ちむしたか價格の監加残つて いる樣てす的とれを一つ。製品の價格は大體 6,500 圓 程度とき〉ましたか, 之の引下けについて何か御意見, 御希望についておききしたい。

高原氏 副産物の問題てすか亞炭タールは量か少い
ことく精製し難いその成分か餘り有用に使用されてい、 ないこと等の點加ら云えは，直接燃料として用途に使 用しては如何てすか，その方か乾溜の熱源になりコー クスを割安にすることになるてはないてしようか。

青柳氏 私共の方てはタールは脫水して練炭の粘結 劑にして居ります。

賀田氏 昔の經驗から爐式は丈を短くしてタールが 分解されて得量か咸する恐れをなくした方か息いと思 いますか。

國井氏 私は一寸御意見と異りむして或程度分解さ。 せて酸等も分子量を小さくした方かター几酸等も利用 度か高くなり高價になります。

賀田氏 それては時間も大分過ぎた樣てすからこれ て座談會を終りたいと存じすす。最後に一言伴會長に。 特願い致します。

伴氏 本日亞炭の畭溜加工に閔与る特別會を開催致 しましたる所，多數のオふが集りになり，有益なお 話を聞き叉座談會子御熱心な討議をされ厚く感謝致す 所でりりす。恐らく現在日本に於ける亞炭乾溜に關 することを全訣網羅し研究の發表を聞き得をしたる機 會を得ました。今後更に緊密に連絡を促ち研究を重ね て行きたいと思つて居りむ寸。時間の關係上充分な御 、討議か出來なかつたこと笺念てありますか, 終始御 繁心な御討議に厚く御䣓申上けます。今後子何卒斯界 のため御盡力下され又引續き本協會のために御支援御 協力あらんことを御願申上けます。重ねて本日の講演 會站ひに本座談會の盛會てありましたことを厚く御䣓 申上けこの會を終りたいと存します。（交責在編集）

\section{會 告}

燃料會馆 3 階檴堂，控室等は本常空いて居ります ら，集會，㳟演會等に御利用下さい，會館々都心にあ

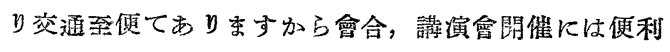
と存します。

國電 東京丈は有樂町 地下鐵 京橋

都電锻治橋又は京橋下車

御利用の節は本協會に御昭會下さい。
昭和 24 年 7 月 20 日印刷納本

昭和 24 年 7 月 25 日酸行

[定傮 100 圆 送料 6 圆] 東京都中央區鲦町 3 , 1

發行人作義定 東京都中央區槇町 3 人 1

編集人二宮保孝

東京都中央區新富町 1 / 7

印刷人石井精一郎 印”刷。所龺京都中央區新富町剧株式會社

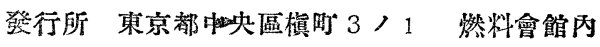

社團 燃料協 會 電話京橋 (56) 3919 （日本出版拹會々員番腤 B214034） 